\title{
Pengaruh Bahasa Daerah Terhadap Sistem Pendidikan di SDN 03 Gunung Tuleh, Kecamatan Gunung Tuleh, Kabupaten Pasaman Barat
}

\author{
Dewi Agustina ${ }^{1 *}$, Anggun Setiawati ${ }^{2}$, Fiqih Triayu Wedari ${ }^{3}$, Lusia Handayani ${ }^{4}$, \\ Mita Mahdalena ${ }^{5}$ \\ ${ }^{1}$ Universitas Islam Negeri Sumatera Utara Medan, Indonesia \\ ${ }^{2}$ Universitas Islam Negeri Sumatera Utara Medan, Indonesia \\ ${ }^{3}$ Universitas Islam Negeri Sumatera Utara Medan, Indonesia \\ ${ }^{4}$ Universitas Islam Negeri Sumatera Utara Medan, Indonesia \\ ${ }^{5}$ Universitas Islam Negeri Sumatera Utara Medan, Indonesia \\ * Corresponding Author. E-mail: ${ }^{1}$ dewiagustina@uinsu.ac.id
}

Receive: 13/02/2021

Accepted: 21/02/2021

Published: 01/03/2021

\begin{abstract}
Abstrak
Bahasa menjadikan syarat yang digunakan manusia untuk berpikir dalam kegiatan berkomunikasi, salah satunya dalam sistem pendidikan. Seperti yang kita ketahui, banyak sekali bahasa daerah digunakan sebagai bahasa komunikasi setiap harinya di lingkungan sekolah. Hal ini dikarenakan tidak semua siswa siswi memahami penggunaan bahasa Indonesia yang baku. Siswa-siswi lebih cenderung menggunakan bahasa Indonesia yang telah terafiliasi oleh bahasa daerah, baik secara pengucapan maupun arti bahasa tersebut. Penelitian ini bertujuan untuk mengetahui intensitas pengaruh penggunaan bahasa daerah terhadap sistem pendidikan di SDN 03 Gunung Tuleh. Penelitian ini merupakan penelitian deskriptif kualitatif dengan menggunakan metode pengumpulan data berupa observasi lapangan. Instrumen penelitian yang digunakan adalah tes lisan dengan menggunakan kata atau kalimat. Pengolahan data dengan menggunakan wawancara (lisan dan dokumentasi). Jumlah sampel dalam penelitian ini adalah keseluruhan peserta didik kelas V SDN 03 Gunung Tuleh yang berjumlah 25 siswa. Penggunaan bahasa Indonesia dalam proses pembelajaran di SDN 03 gunung tuleh ternyata dipengaruhi oleh bahasa ibu atau bahasa sehari-hari. Dari hasil penelitian ditemukan bahwa jumlah siswa siswi kelas $\mathrm{V}$ berjumlah 25 orang, dari jumlah tersebut terdapat 15 siswa siswi yang dapat memahami bahasa Indonesia dengan baik dan benar dan terdapat 10 orang yang tidak dapat memahami bahasa Indonesia dengan baik dan benar. Dapat dipersentasekan bahwa siswa-siswi yang dapat menggunakan bahasa Indonesia dengan baik dan benar sebanyak $40 \%$ dan yang tidak dapat menggunakan bahasa Indonesia dengan baik dan benar sebanyak $60 \%$.
\end{abstract}

Kata Kunci: Bahasa Daerah, Sistem Pendidikan, Siswa.

\section{The Influence of Regional Languages on the Education System at SDN 03 Gunung Tuleh, Gunung Tuleh District, West Pasaman Regency}

\begin{abstract}
Language is a condition used by humans to think in communication activities, one of which is in the education system. As we know, many regional languages are used as the language of communication every day in the school environment. This is because not all students understand the use of standard Indonesian. Students are more likely to use Indonesian which has been affiliated with the regional
\end{abstract}


language, both in terms of pronunciation and meaning of the language. This study aims to determine the intensity of the influence of the use of local languages on the education system at SDN 03 Gunung Tuleh. This research is a qualitative descriptive study using data collection methods in the form of field observations. The research instrument used was an oral test using words or sentences. Data processing using interviews (oral and documentation). The number of samples in this study were all fifth grade students at SDN 03 Gunung Tuleh, totaling 25 students. The use of Indonesian in the learning process at SDN 03 Gunung Tuleh is apparently influenced by the mother tongue or everyday language. From the results of the study it was found that the number of fifth grade students was 25 people, from that number there were 15 students who could understand Indonesian properly and correctly and there were 10 people who could not understand Indonesian properly and correctly. It can be shown that $40 \%$ of students who can use Indonesian properly and correctly and who cannot use Indonesian properly and correctly are $60 \%$.

Keywords: Regional Language, Education System, Students.

\section{Pendahuluan}

Bahasa daerah merupakan simbol atau bunyi yang bermakna yang berartikulasi yang digunakan di suatu wilayah yang dipakai sebagai bahasa penghubung antar daerah di wilayah Indonesia. Seiring dengan perkembangan era globalisasi yang semakin maju maka tingkat bahasa juga berpengaruh dan sangat penting.

Pengertian Bahasa menurut Wibowo adalah sistem simbol bunyi yang bermakna dan berartikulasi (dihasilkan oleh alat ucap) yang bersifat arbitrer dan konvensional, yang dipakai sebagai alat berkomunikasi oleh sekelompok manusia untuk melahirkan perasaan dan pikiran (Wahyu Wibowo, 2001: 3). Sedangkan daerah adalah tempat sekeliling atau yang termasuk di lingkungan suatu kota (wilayah dan sebagainya) (Wjs Poerwo Darminto, 1993: 220).

Dari pengertian di atas dapat disimpulkan bahwa bahasa daerah merupakan simbol atau bunyi yang bermakna dan berartikulasi yang digunakan di lingkungan suatu kota atau wilayah yang dipakai sebagai bahasa penghubung antar daerah di wilayah Republik Indonesia. Bahasa daerah merupakan bagian dari kebudayaan Indonesia yang hidup sesuai dengan penjelasan Undang Undang Dasar 45 yang berhubungan dengan bab XV pasal 36.

Bahasa daerah merupakan bahasa tradisional di sebuah daerah yang menjadi warisan turun temurun bagi masyarakat pemakai di tempat bahasa itu digunakan (Jos Daniel Parera, 1989: 16).
Sebab B1 adalah bahasa ibu, yang dipelajari yang digunakan sejak kecil dalam keluarga; sedangkan B2 adalah bahasa yang baru kemudian dipelajari, yakni setelah menguasai B1. Dalam keadaan penguasaan tehadap B1 lebih baik dari pada B2, dan juga kesempatan untuk menggunakanya lebih luas maka ada kemungkinan B1 si penutur akan memengaruhi B2-nya. pengaruh ini dapat berupa peristiwa yang disebut interfrensi, baik pada tataran fonologi, morfologi, sintaksis, maupun tataran leksikon.

Seberapa pengaruh B1 terhadap B2 adalah tergantung pada tingkat penguasaanya terhadap B2. Para ahli pengajaran bahasa kedua percaya bahwa bahasa pertama atau bahasa yang diperoleh sebelumnya, berpengaruh terhadap proses penguasaan bahasa kedua peserta didik. Bahkan bahasa pertama telah lama dianggap sebagai pengganggu peserta didik dalam menguasai bahasa kedua. Pandangan ini lahir karena secara disadari atau tidak, peserta didik melakukan transfer atau memindahkan unsurunsur bahasa pertama ke dalam struktur bahasa kedua. Akibatnya terjadilah apa yang disebut pergantian struktur dan kode-kode bahasa dari bahasa pertama terhadap bahasa kedua yang digunakanya. Jika struktur bahasa pertama sama atau mirip dengan bahasa kedua, peserta didik akan lebih mudah mentransfernya. Jika perbedaan antar keduanya tidak disadari oleh peserta didik, kemungkinan terjadi negatif, yang pada akhirnya memunculkan pristiwa interferensi (sengaja menggunakan kaidah bahasa pertama 
untuk bahasa kedua). Kesilapan (kesalahan yang dibuat insedental karena tidak sengaja), dan kesalahan yaitu kesalahan yang muncul secara konsisten karena ketidaktahuan. Itulah sebabnya, semakin besar perbedaan struktur antara yang ada dalam bahasa pertama dengan yang ada dalam bahasa kedua, usaha yang harus dilakukan oleh peserta didik dalam memperoleh dan menguasai bahasa kedua cenderung lebih berat dan sukar bila dibandingkan apabila kedua bahasa itu memiliki kesamaan. Dengan demikian dapat diketahui bahwa bahasa pertama berpengaruh terhadap proses penguasaan bahasa kedua. Pengaruh bahasa pertama terhadap proses belajar bahasa kedua juga dapat diamati dari apa yang kemudian terkenal dengan istilah bahasa antara atau intalic. Bahasa antara adalah suatu gejala pemakaian bahasa yang muncul akibat peserta didik belum sepenuhnya dapat meninggalkan kebiasaannya dalam berbahasa pertama, tetapi belum sepenuhnya menguasai bahasa kedua.

Di dalam kedudukanya sebagai bahasa daerah, seperti bahasa Jawa, bahasa Sunda, bahasa Bali, bahasa Bugis, bahasa Makassar dan sebagainya. Bahasa daerah berfungsi: lambang kebanggaan daerah, lambang identitas daerah, Sarana perhubungan di dalam keluarga dan masyarakat daerah, sarana pengembangan serta pendukug kebudayaan daerah, bahasa daerah dapat digunakan sebagai bahasa pengantar dalam tahap awal pendidikan apabila diperlukan dalam penyampaian pengetahuan dan/atau keterampilan tertentu (Manan: 8).

Adapun Kedudukan bahasa daerah yaitu: penunjang bahasa nasional, sumber bahan pengembanagan bahasa nasional, bahasa pengantar pada tingkat permulaan di sekolah dasar di daerah tertentu untuk memperlancar pengajaran bahasa Indonesia dan mata pelajaran lain. Jadi, bahasa-bahasa daerah ini secara sosial politik merupakan bahasa kedua.

Berikut beberapa pengaruh atau dampak penggunaan bahasa daerah terhadap bahasa Indonesia. Dampak positifnya adalah: bahasa Indonesia memiliki banyak kosa kata, sebagai kekayaan budaya bangsa Indonesia, sebagai identitas dan ciri khas dari suatu suku dan daerah, dan menimbulkan keakraban dalam berkomunikasi. Dampak negatifnya adalah: bahasa daerah yang satu sulit di pahami oleh daerah lain, warga negara asing yang ingin belajar bahasa Indonesia menjadi kesulitan karena terlalu banyak kosa kata, masyarakat menjadi kurang paham dalam menggunakan bahasa Indonesia yang baku karena sudah terbiasa menggunakan bahasa, dapat menimbulkan kesalahpahaman.

Ada beberapa peran bahasa daerah di dalam persatuan bangsa, yaitu: sebagai lambang kebanggaan nasional, sebagai sarana perhubungan antara budaya dan daerah, sebagai bahasa pengantar resmi di lembagalembaga pendidikan, sebagai penunjang bahasa nasional, dan sebagai sumber bahan pengembangan bahasa nasional.

Salah satu daerah yang masih kental menggunakan bahasa daerah dalam lingkungan sekolah adalah daerah Talang kuning, kecamatan Gunung tuleh tepatnya di SDN 03 Gunung Tuleh Kabupaten Pasaman Barat.

Bahasa umum yang selalu digunakan oleh masyarakat Talang kuning kecamatan Gunung tuleh yaitu bahasa Mandailing yang biasa dikenal dengan bahasa daerah, di mana bahasa daerah yang digunakan dalam lingkungan formal seperti dalam lingkungan sekolah yang berdampak bagi peserta didik itu sendiri dalam mengikuti proses pembelajaran di sekolah.

Dengan hal ini bahasa daerah sangat mempengaruhi hasil belajar bahasa Indonesia. Di dalam perkembangan pendidikan satu diantaranya dipengaruhi oleh budaya. Maka dari itu perlu melakukan suatu tindakan baik dari pendidik itu sendiri maupun bagi orang tua.

Bahasa daerah boleh saja digunakan karena bahasa daerah juga sebagai salah satu bahasa pengantar, namun jangan terlalu sering digunakan, karena jika sering digunakan maka akan memberi dampak negatif bagi peserta didik seperti peserta didik tidak dapat mengerti apa yang dijelaskan oleh pengajar, peserta didik tidak dapat berkomunikasi dengan orang asing, peserta didik tidak dapat 
berbicara formal dengan pengajar maupun menjawab pertanyaan yang diberikan dan sulit menerima mata pelajaran lain selain bahasa Indonesia.

\section{Metode}

Penelitian lapangan ini bersifat kualitatif, Menurut Bogdan \& Taylor dalam (Maleong, 2007) Penelitian kualitatif didefinisikan sebagai penelitian yang prosedurnya dapat memperoleh hasil data deskriptif yang berbentuk kata-kata tertulis ataupun secara lansung pelaku yang diamati. Pendekatan yang dipakai pada saat melaksanakan penelitian ini ialah pendekatan deskriptif kualitatif. Pendekatan deskriptif kualitatif adalah pendekatan yang mengarahkan dapat memecahkan masalah dengan cara memaparkan atau menggambarkan apa adanya hasil penelitian (Riduwan, 2010). Penelitian ini yang menjadi subyek penelitian adalah siswa kelas 5 dan 6 di SDN 03 Gunung Tuleh . Tempat pelaksanaan penelitian ini bertempat di SDN 03 Gunung Tuleh. Pengumpulan hasil yang diperoleh pada pengawasan ini penulis menggunakan metode observasi. Observasi ini dilakukan dengan adanya pengawasan denga cara langsung pada objek pengamata dalam memperhatikan kegiatan jarak dekat (Riduwan, 2010). Metode ini digunakan untuk mengamati, mendengarkan, dan mencatat aktifitas pada proses pembelajaran tentang Pengaruh Bahasa Daerah Terhadap Sistem Pendidikan di SDN 03 Gunung Tuleh.

\section{Hasil dan Pembahasan}

Proses belajar mengajar bahasa Indonesia mengalami kesulitan di tengah pembelajaran. Kendalanya yaitu siswa SDN 03 Gunug Tuleh merasa tidak terbiasa dengan memakai bahasa Indonesia pada saat berkomunikasi siswa lebih merasa nyaman untuk menggunakan bahasa daerah atau bahasa ibunya. Sampai saat ini bahasa Mandailing menjadi masih menjadi salah satu bahasa yang mempunyai peranan sangat penting bagi kehidupan masyarakat Gunung Tuleh. Sebagai bahasa yang pertama dipelajari di lingkungan, bahasa daerah memiliki dalam proses pendidikan anak bangsa. Seiring dengan perkembangan globalisasi, banyak lingkungan masyarakat bahasa Mandailing menjadi lebih utama. Untuk mengatasi kesalahan berbahasa Indonesia dengan tepat, dalam pengunaan bahasa haruslah berusaha untuk menaikkan dari segi keterampilan pada mempraktikkan bahasa Indonesia yang sesuai dengan aturan yang ada.

Keadaan tersebut penulis asumsikan bahwa hal ini dampak dari tidak semua siswa di lingkungan membiasakan dirinya menggunakan bahasanya adalah bahasa mandailing, anak akan mudah mendapatkan adanya bahasa Indonesia menjadi bahasa kedua disekolahnya. Upaya peneliti dalam permasalahan ini yaitu peserta didik diwajibkan untuk mencari atau menambah kosakata lebih banyak lagi, rajin membaca buku baik buku pembelajaran maupun buku lainnya, bisa juga membaca cerpen atau bacaan lainnya agar menambah perluasaaan berbahasa, dan membiasakan berkomunikasi menggunkan bahasa Indonesia yang santun dan tidak menyinggung.

Berdasarkan hasil observasi yang telah kami lakukan dengan menggunakan metode penelitian deskriptif kualitatif maka dapat disimpulkan bahwa penggunaan bahasa daerah masih sangat tinggi sehingga pendidik merasa sangat kesulitan dalam menjelaskan proses pembelajaran dengan menggunakan bahasa Indonesia.

Dalam hasil penelitian ini terdapat banyak hal yang sangat signifikan negatif terhadap penggunaan bahasa Indonesia dalam proses belajar mengajar di SDN 03 Gunung tuleh.

Berdasarkan hasil observasi intensitas penggunaan bahasa daerah peserta didik di kelas 5 SDN 03 Gunung Tuleh dapat dikemukakan bahwa intensitas penggunaan bahasa daerah peserta didik kelas 5 SDN 03 Gunung tuleh yaitu dengan $60 \%$ siswa yang masih sangat minim dengan pemahaman bahasa Indonesianya sedangkan penggunaan dengan siswa yang masih memahami bahasa Indonesia adalah $40 \%$ siswa. 
Tabel 1. Perbandingan Pemahaman Siswa Terhadap Bahasa Indonesia

\begin{tabular}{|c|l|c|}
\hline No. & $\begin{array}{l}\text { Pemahaman Siswa } \\
\text { Terhadap Bahasa } \\
\text { Indonesia }\end{array}$ & $\begin{array}{c}\text { Persentase } \\
\mathbf{( \% )}\end{array}$ \\
\hline 1. & $\begin{array}{l}\text { Siswa dengan } \\
\text { pemahaman bahasa } \\
\text { Indonesia }\end{array}$ & $60 \%$ \\
\hline 2. & $\begin{array}{l}\text { Siswa dengan } \\
\text { pemahaman bahasa } \\
\text { Indonesia yang } \\
\text { kurang baik }\end{array}$ & $40 \%$ \\
\hline
\end{tabular}

Intensitas penggunaan Bahasa daerah berpengaruh terhadap Hasil Belajar Bahasa Indonesia Peserta Didik Kelas 5 SDN 03 Gunung Tuleh. Berdasarkan hasil observasi yaitu dengan metode deskriptif kualitatif yang telah diuraikan, maka dapat dikemukan bahwa Intensitas Penggunaan Bahasa daerah berpengaruh terhadap Hasil Belajar Bahasa Indonesia Peserta Didik Kelas 5 SDN 03 Gunung Tuleh dan memiliki hubungan yang tidak signifikan. Karena para siswa-siswi kesulitan dalam memahami bahasa Indonesia.

Dari penjelasan di atas dapat disimpulkan bahwa penggunaan bahasa daerah terhadap sistem pendidikan khususnya di kelas 5 di SDN 03 Gunung sangat menghasilkan pengaruh yang negatif. Karena dalam sistem pendidikan penggunaan hasilnya Indonesia masih sangat rendah terutama dalam pelajaran bahasa Indonesia nilai siswa rata-rata sangat rendah. Hal ini disebabkan karena faktor kebiasaan siswa yang selalu menggunakan bahasa daerah dalam pergaulan sehari-hari, baik dalam lingkungan rumah maupun sekolah.

\section{Simpulan}

Berdasarkan hasil penelitian dan pembahasan sebelumnya maka diperoleh beberapa kesimpulan sebagai berikut:

Penggunaan bahasa daerah pada peserta didik kelas SDN 03 Gunung Tuleh masih sangat tinggi. Jika dilihat dalam tabel tingkat penguasaan materi, hasil penggunaan bahasa daerah masuk dalam kategori sangat tinggi sebesar $60 \%$. Jika dilihat dalam tabel tingkat penguasaan materi, hasil penggunaan bahasa Indonesia masuk dalam kategori sangat rendah sebesar 40\%. Dapat disimpulkan bahwa penggunaan bahasa daerah terhadap sistem pendidikan kelas $\mathrm{V}$ SDN 03 Gunung Tuleh menghasilkan pengaruh yang negatif. Hal ini ditandai dengan sistem pendidikan di SDN 03 Gunung Tuleh yang masih tergolong sangat rendah.

\section{Daftar Pustaka}

[1] Hamalik, Oemar. (2002). Perencanaan Pengajaran Berdasarkan Pendekatan Sistem. Jakarta: Bumi Aksara.

[2] Kusmawanto, N. Yoki, et.al. (2019). Pengaruh Bahasa Ibu Terhadap Pidato Persuasif di SMPN 2 Batujajar. Jurnal Pendidikan Bahasa dan Sastra Indonesia, 2(3), 461-466.

[3] Mastuhu. (1994). Dinamika Sistem Pendidikan Pesantren. Jakarta: INIS.

[4] Made, Pidarta. (2002). Landasan Kependidikan Stimulus IImu Pendidikan Bercorak Indonesia. Jakarta: Kalam Mulia.

[5] Rahman, Astuti, et.al. (2016). Pengaruh Bahasa Daerah Terhadap Hasil Belajar Bahasa Indonesia Peserta Didik Kelas I SD Inpres MAKI Kecamatan Lamba-Leda Kabupaten Manggrai Timur. Jurnal Pendidikan Dasar Islam, 3(2), 77-79. http://jurnal.radenfatah.ac.id/index.php/b ioilmi/article/view/1133.

[6] Sanjaya, Wina. (2007). Strategi Pembelajaran Berorientasi Standar Proses Pendidikan. Jakarta: Kencana. 